\title{
Review Paper on Different shaped Microstrip Patch Antenna for Wireless Communication Systems
}

\author{
Madan Sahu \\ M.tech. Scholar \\ Oriental College of Technology \\ Bhopal
}

\author{
Prateek Wankhade \\ Asst. Professor \\ Oriental College of Technology \\ Bhopal
}

\author{
Sumit Gupta \\ Head of Department \\ Oriental College of Technology \\ Bhopal
}

\begin{abstract}
A compact micro strip patch antenna became a very useful in communication systems. Properties such as compactness, light weight, high bandwidth make it a good candidate of communication system. This paper reviews the performance analysis of bandwidth enhancement of a monopole patch antenna with V-shaped slot for car-to-car and WLAN communications (2016), omnidirectional wideband E-shaped cylindrical patch antennas (2016), design of wideband/dualband E-shaped patch antennas with the transmission line mode theory (2016), patch size reduction of rectangular micro strip antennas by means of a cuboid ridge (2015) and micro strip rectangular patch antenna for S and X Band Applications (2016). The paper also discusses the technology used in order to bring the required changes in terms of improved performance characteristics.
\end{abstract}

\section{Keywords}

WLAN (Wireless local area network), Micro strip antenna, Monopole antenna, Dual band antenna, RMPA (Rectangular micro strip patch antenna), cylindrically conformal antenna array, omnidirectional antennas, wide-band antennas, wideband, wireless, car to car communication (C2C), Eshaped patch antenna (ESPA).

\section{INTRODUCTION}

A compact microstrip patch antennas became very useful, primarily for space craft and aircraft purpose. Today they are applicable in almost every communication systems such as radar systems, missile technology, mobile communication, GPS service for land vehicles, maritime vessels to find out their exact position etc. The reason is being its advantages such as light weight, low profile, simple and inexpensive, planner structure using advanced printed circuit technology, compatible with MMIC designs, mechanically stable when mounted on rigid body. In this paper we have reviewed some papers about microstrip patch antenna and will see the performance of parameter on the basis of comparative analysis of bandwidth enhancement and return loss value of different papers. Extensive research work is being carried out in the field of Microstrip patch antennas. The development in the context of RMPA is our focus area. The following review focused on the comparative study of five different research works; in a recent study Hang Wong et al. designed an antenna with vertical polarization for Car-to-Car and WLAN communications in [1]. Designed geometry consists of an equilateral triangular patch with certain shorting pins. Designed geometry could be used for effective resistance and reactance reduction of input impedance. The implementation of $\mathrm{V}$-shaped slot is equivalent to a capacitance loading (see Figure 1), which was used to reduce the resistance and the reactance of the antenna, contributed a wider impedance bandwidth. The proposed antenna had the impedance bandwidth of $32.20 \%$ (see Figure 2), with the peak gain of $6.50 \mathrm{dBi}$ over the operating bandwidth. The return loss of the mounted antenna was measured around $-20 \mathrm{~dB}$. The proposed antenna was simple, low cost, and could be easily mounted on the car roof. These characteristics made the designed antenna suitable for $\mathrm{C} 2 \mathrm{C}$ and WLAN communications.

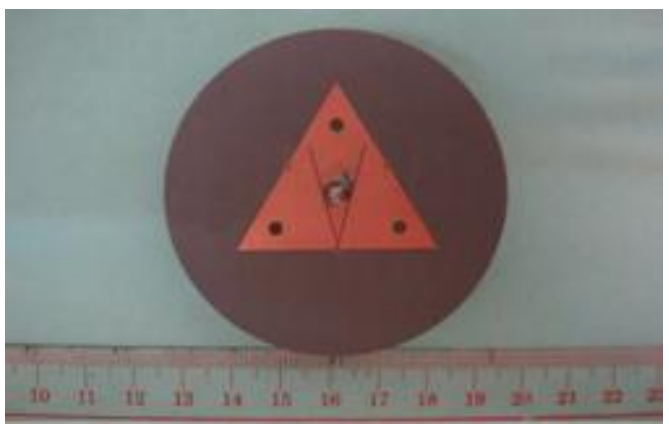

Figure 1. Designed v-shaped antenna [1]

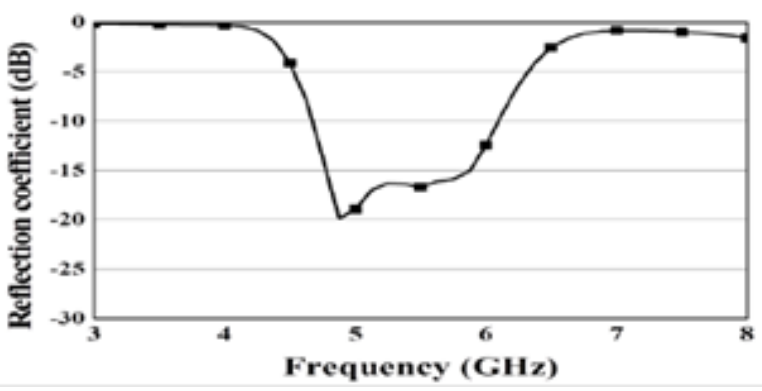

Figure 2. Return loss vs frequency plot of v- shaped antenna [1]

In [2] alexander ye. svezhentsev et al. designed a wide-band omnidirectional cylindrical microstrip antenna with two new E shapes. The geometry was designed on a low permittivity flexible textile substrate. Both antennas (Fig.3 and Fig.5) had shown Omni directionality in the horizontal plane, wide-band behavior (for the first antenna) and low side-lobe levels (for the second antenna). The antenna was designed to have $33 \%$ and $21 \%$ bandwidth, and $2.98 \mathrm{dBi}$ and $4.56 \mathrm{dBi}$ gains, respectively. The return loss values obtained from antenna 1 $-25.15 \mathrm{~dB}$ (see Figure 4) and for the antenna 2 was $-19 \mathrm{~dB}$ (see Figure 6). This paper concludes that textile substrate is very promising to be used in WBAN applications. 


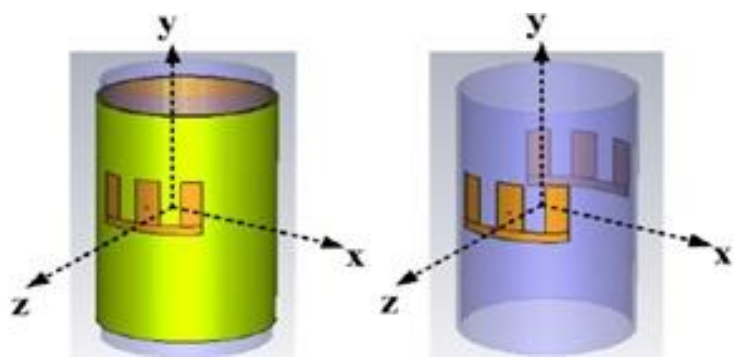

Figure 3. The non-transparent (a) Transparent (b) Side view of double E-shaped cylindrical patch antenna [2]

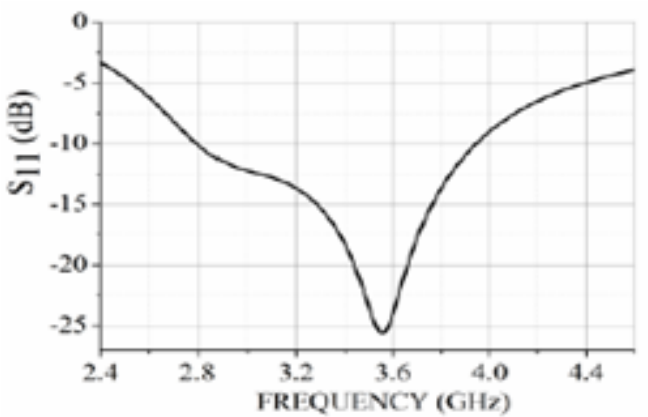

Figure 4. Return loss v/s Frequency plot of double Eshaped cylindrical patch antenna [2]

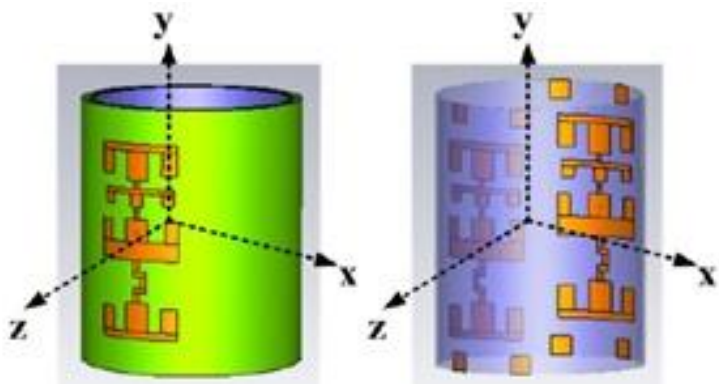

Figure 5. The non-transparent (a) Transparent (b) Side front view of double E-shaped quadruple patch antenna [2]

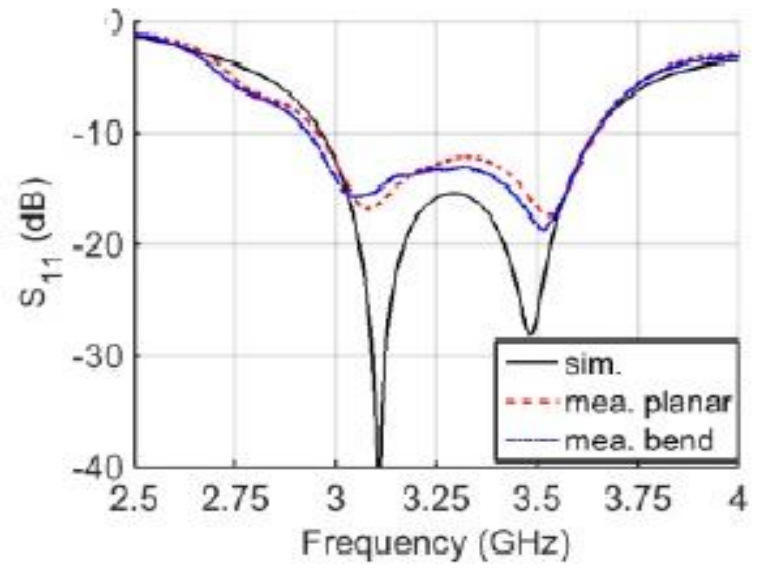

Figure 6. Return loss characteristics of double E-shaped quadruple patch antenna [2]

Keisuke Noguchi et al. proposed a new model for E-shaped patch antennas (ESPA) using the multi-conductor transmission line mode theory (the modal theory) in [3]. Paper described that transmission line and radiation modes were generated on the E Shaped Patch Antenna (see Figure 7) and an equivalent circuit was derived from the modal theory. The equivalent circuit was designed to obtain wideband and multiband characteristics. For wideband ESPA, maximum bandwidth was derived. The simulated and measured return loss value was around $-25 \mathrm{~dB}$ and $-22.5 \mathrm{~dB}$. The impedance bandwidth for the wideband design was evaluated $27.7 \%$ (see Figure 8)

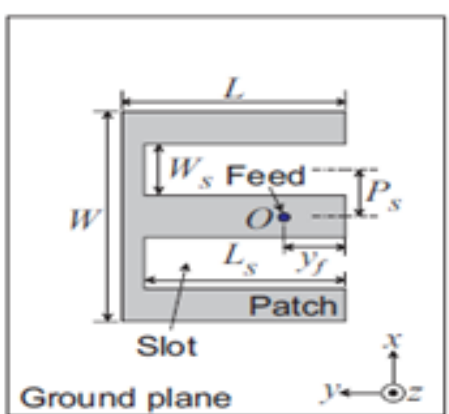

(a)

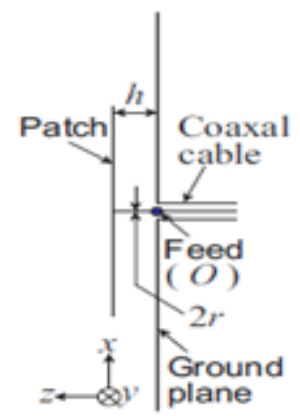

(b)
Figure 7. Geometry of E- shaped patch antenna [3]

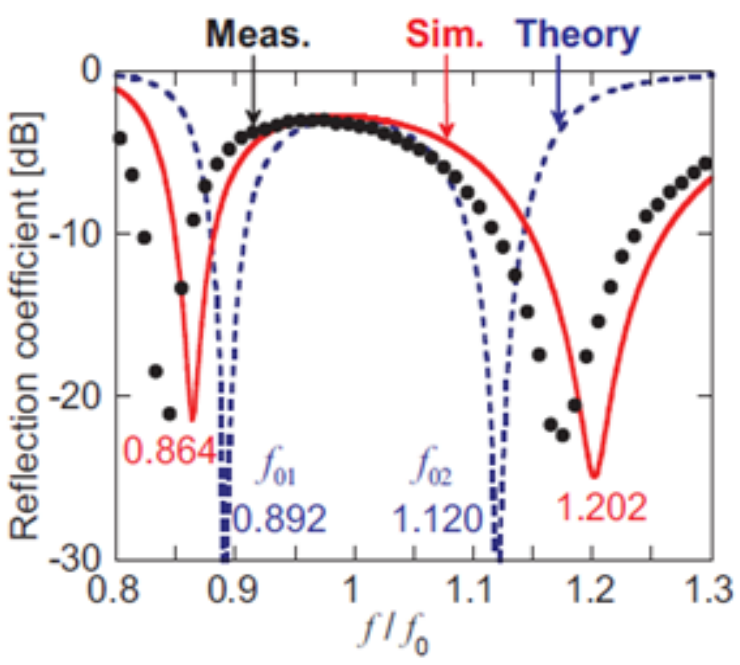

Figure 8. Return loss vs frequency plot [3]

In [4] Alireza motevasselian and William G. whittow presented an effective approach for the reduction in patch size by inductively loading the patch using a cuboid ridge. The cuboid ridge dimensions were 29x7x1.6 mm (see Figure 9). The fabricated antenna was found to be resonated at 2.35 GHz. Cuboid ridge was inserted as the part of the transmission line model of the patch antenna. The results were generated using CST studio simulation tool. The simulated and measured return loss value was found to be around $-15 \mathrm{~dB}$ and $-21.5 \mathrm{~dB}$ respectively. The designed geometry was fed by $50 \Omega$ characteristics coaxial line.

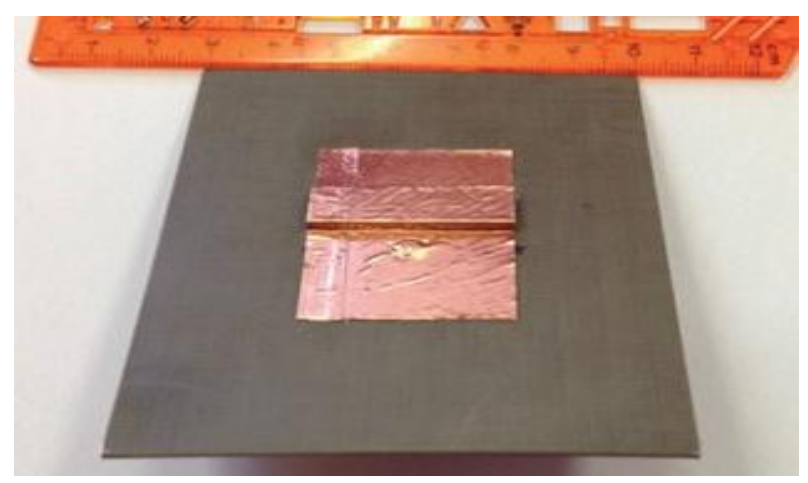

Figure 9. Fabricated antenna design [4] 


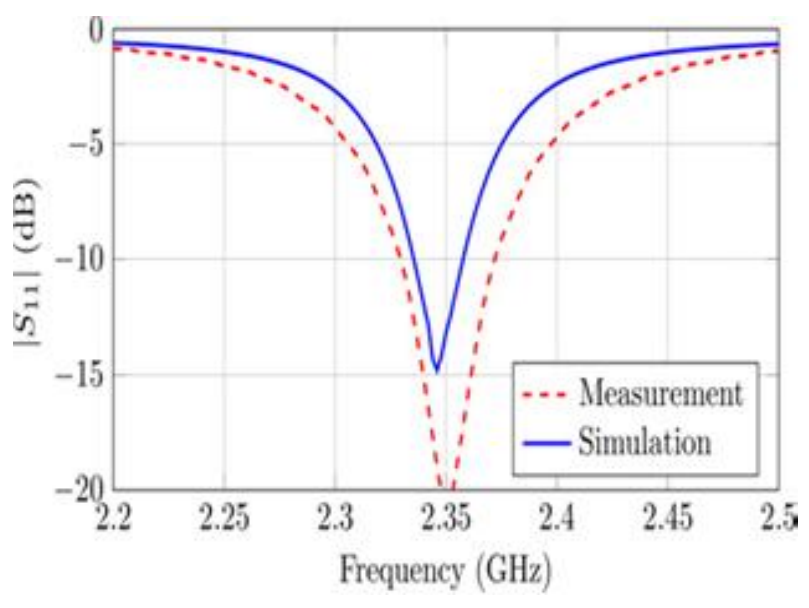

Figure 10. Return loss vs frequency plot [4]

Amandeep Kaur Sidhu and Jagtar Singh Sivia proposed an RMPA with circular slot applicable for $\mathrm{S}$ band and $\mathrm{X}$ band applications in [5]. Rogers RT/Duroid material was used as design substrate with 2.2 dielectric constant. Probe feed is used to provide the excitation. This paper is based Miniaturisation of antenna structures. Proposed geometry size of conventional antenna was reduced to $48 \%$. The maximum return loss was obtained in the second iteration as $-16.20 \mathrm{~dB}$ (see Figure 12). The gain of the antenna was calculated 8.32 $\mathrm{dBi}$. Proposed antenna was designed and simulated using high frequency structural simulator (HFSS).

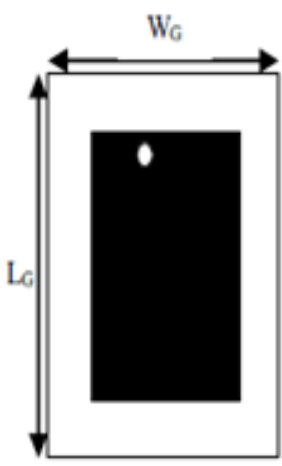

(a)

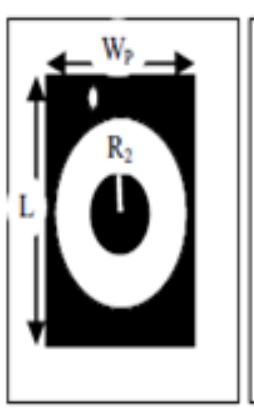

(b)

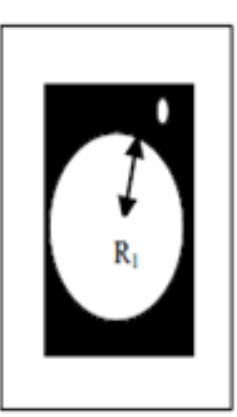

(c)
Figure 11. Designed RMPA (a) $0^{\text {th }}$ iteration RMPA1 $1^{\text {st }}$ iteration RMPA (c) $2^{\text {nd }}$ iteration RMPA [5]

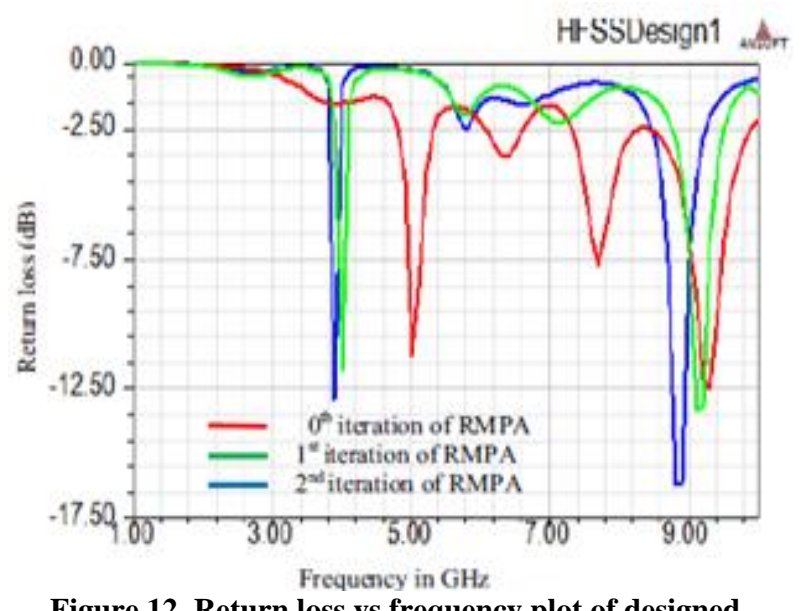

Figure 12. Return loss vs frequency plot of designed RMPA [5]
Table 1 Literature Review

\begin{tabular}{|c|c|c|c|c|c|c|}
\hline $\begin{array}{l}\text { Par } \\
\text { ame } \\
\text { ters }\end{array}$ & [1] & \multicolumn{2}{|c|}{ [2] } & [3] & [4] & [5] \\
\hline Year & 2016 & \multicolumn{2}{|c|}{2016} & 2016 & 2015 & 2016 \\
\hline $\begin{array}{l}\text { Aut } \\
\text { hor }\end{array}$ & $\begin{array}{l}\text { Hang } \\
\text { Wong } \\
\text { et al. }\end{array}$ & \multicolumn{2}{|c|}{$\begin{array}{l}\text { Alexander } \\
\text { Ye. } \\
\text { Svezhentsev } \\
\text { et al. }\end{array}$} & $\begin{array}{c}\text { Keisu } \\
\text { ke } \\
\text { Nogu } \\
\text { chi et } \\
\text { al. }\end{array}$ & $\begin{array}{c}\text { Alirez } \\
\text { a } \\
\text { motev } \\
\text { asselia } \\
\text { n }\end{array}$ & $\begin{array}{c}\text { Aman } \\
\text { deep } \\
\text { Kaur } \\
\text { Sidhu }\end{array}$ \\
\hline $\begin{array}{l}\text { Publ } \\
\text { icati } \\
\text { on }\end{array}$ & $\begin{array}{c}\text { IEEE } \\
\text { Transa } \\
\text { ctions } \\
\text { on } \\
\text { Vehic } \\
\text { ular } \\
\text { Techn } \\
\text { ology }\end{array}$ & \multicolumn{2}{|c|}{$\begin{array}{c}\text { IEEE } \\
\text { Transaction } \\
\text { s on } \\
\text { Antennas } \\
\text { and } \\
\text { Propagation }\end{array}$} & $\begin{array}{c}\text { IEEE } \\
\text { Trans } \\
\text { action } \\
\text { s on } \\
\text { Anten } \\
\text { nas } \\
\text { and } \\
\text { Propa } \\
\text { gation }\end{array}$ & $\begin{array}{c}\text { IET } \\
\text { Micro } \\
\text { waves } \\
\text { Anten } \\
\text { nas \& } \\
\text { Propa } \\
\text { gation }\end{array}$ & $\begin{array}{l}\text { IEEE } \\
\text { WISP } \\
\text { NET } \\
\text { Confe } \\
\text { rence }\end{array}$ \\
\hline $\begin{array}{l}\text { Soft } \\
\text { ware }\end{array}$ & $\begin{array}{c}\text { CST } \\
\text { Micro } \\
\text { wave } \\
\text { Studio }\end{array}$ & \multicolumn{2}{|c|}{$\begin{array}{c}\text { CST } \\
\text { Microwave } \\
\text { Studio }\end{array}$} & $\begin{array}{c}\text { Ansof } \\
t \\
\text { HFSS }\end{array}$ & $\begin{array}{c}\text { CST } \\
\text { Micro } \\
\text { wave } \\
\text { Studio }\end{array}$ & $\begin{array}{l}\text { Ansoft } \\
\text { HFSS }\end{array}$ \\
\hline $\begin{array}{l}\text { Feed } \\
\text { ing } \\
\text { met } \\
\text { hod }\end{array}$ & $\begin{array}{c}\text { Probe } \\
\text { feed }\end{array}$ & \multicolumn{2}{|c|}{ Probe feed } & $\begin{array}{c}\text { Probe } \\
\text { feed }\end{array}$ & $\begin{array}{c}\text { Coaxi } \\
\text { al line } \\
\text { feed }\end{array}$ & $\begin{array}{c}\text { Coaxi } \\
\text { al line } \\
\text { feed }\end{array}$ \\
\hline $\begin{array}{c}\text { Max } \\
\text { imu } \\
\mathrm{m} \\
\text { retur } \\
\mathrm{n} \\
\text { loss }\end{array}$ & $\begin{array}{l}-20 \\
d B\end{array}$ & $\begin{array}{c}\text { Ant } \\
1\end{array}$ & $\begin{array}{c}- \\
25.1 \\
\mathrm{~dB} \\
-19 \\
\mathrm{~dB}\end{array}$ & $\begin{array}{l}-25 \\
\mathrm{~dB}\end{array}$ & $\begin{array}{c}-21.5 \\
\mathrm{~dB}\end{array}$ & $\begin{array}{c}-16.20 \\
d B\end{array}$ \\
\hline $\begin{array}{c}\text { Freq } \\
\text { uenc } \\
\mathrm{y} \\
\text { rang } \\
\mathrm{e}\end{array}$ & $\begin{array}{l}4.82 \\
\text { to } \\
6.67 \\
\mathrm{GHz}\end{array}$ & \multicolumn{2}{|c|}{$\begin{array}{c}2.5 \text { to } 4 \\
\mathrm{GHz}\end{array}$} & $\begin{array}{c}0.8 \text { to } \\
2.40 \\
\mathrm{GHz}\end{array}$ & $\begin{array}{c}2.2 \text { to } \\
2.5 \\
\mathrm{GHz}\end{array}$ & $\begin{array}{c}1 \text { to } \\
10 \\
\mathrm{GHz}\end{array}$ \\
\hline $\begin{array}{l}\text { Ban } \\
\text { dwi } \\
\text { dth }\end{array}$ & $32.2 \%$ & $\begin{array}{c}\text { Ant } \\
1 \\
\text { Ant } \\
2\end{array}$ & $21 \%$ & $\begin{array}{c}27.7 \\
\%\end{array}$ & & \\
\hline $\begin{array}{c}\text { VS } \\
\text { WR }\end{array}$ & $\begin{array}{l}\text { Less } \\
\text { than } 2\end{array}$ & \multicolumn{2}{|c|}{ Less than 2} & $\begin{array}{l}\text { Less } \\
\text { than } 2\end{array}$ & $\begin{array}{l}\text { Less } \\
\text { than } 2\end{array}$ & $\begin{array}{l}\text { Less } \\
\text { than } 2\end{array}$ \\
\hline
\end{tabular}

\section{CONCLUSION}

Review provides an insight in evaluating the performance characteristics of micro strip patch antenna. The impedance bandwidth can be enhanced by slot implementation on to patch. This review also gives the effects of two feeding techniques in terms of return loss and other parameters. It was also inferred that by introducing slot of different shapes (Eshape, half U-shape and V-shape), we can avoid interference near their corresponding band notch frequencies. Single band characteristics can be converted into multiband characteristics slot implementation onto the patch. Return loss and bandwidth characteristics of the antenna can also be improved using slot implementation. This review paper also helps in deriving the filter characteristics. 


\section{REFERENCES}

[1] Hang Wong et al. "Bandwidth Enhancement of a Monopolar Patch Antenna with V-shaped Slot for Carto-Car and WLAN Communications" IEEE Transactions on Vehicular Technology, Vol. 65, No. 3, March 2016, pp: 1130-1136.

[2] Alexander Ye. Svezhentsev et al. "Omnidirectional Wideband E-Shaped Cylindrical Patch Antennas" IEEE Transactions on Antennas and Propogation, Vol. 64, No. 2, February 2016, pp: 796-800.

[3] Keisuke Noguchi et al. 2016 "Design of Wideband/DualBand E-Shaped Patch Antennas With the Transmission Line Mode Theory" IEEE Transactions on Antennas and Propogation, Vol;. 64, No. 4, April 2016, pp: 1183-1192.
[4] Alireza Motevasselian et al. "Patch size reduction of rectangular microstrip antennas by means of a cuboid ridge" IET Microwaves, Antennas \& Propagation, Vol. 9, Iss. 15, July 2015, pp: 1727-1732.

[5] Amandeep Kaur Sidhu et al. "Microstrip Rectangular Patch Antenna For S And X Band Applications" IEEE WiSPNET 2016 conference, 2016, pp: 248-251.

[6] M. Ali et al. "Wide-Band/Dual-Band Packaged Antenna for 5-6 GHz WLAN Application" IEEE Antennas and Wireless Propogation, Vol. 52, Issue 2, February 2004.

[7] U. Chakraborty et al. "Compact Dual-Band Microstrip Antenna for IEEE 802.11a WLAN Application” IEEE Antennas and Wireless Propogation Letters, VOL. 13, 2014, pp: 407-410. 